\title{
ARSITEKTUR BIOPHILIC UNTUK MENDUKUNG PENGEMBANGAN DESAIN HUNIAN DI ERA KEGIATAN WORK FROM HOME (PANDEMIC COVID 19) STUDI KASUS PERUMAHAN NARAYA BSB SEMARANG
} Biophilic Architecture To Support Residential Design Development In The Era of Work From Home Activities (Pandemic Covid 19) Case Study The Naraya Cluster BSB City Semarang

\author{
Christian Moniaga \\ Program Studi Arsitektur, Universitas Katolik Soegijapranata \\ Jl. Pawiyatan Luhur IV/1 Semarang \\ christianmoniaga@unika.ac.id
}

\begin{abstract}
Abstrak
Pandemi Covid-19 mengharuskan manusia untuk dalam kurun waktu tertentu menghindari interaksi langsung antar manusia. Untuk menjaga produktivitas kerja, maka banyak langkah yang dilakukan termasuk kegiatan bekerja dari rumah (work from home). Perubahan pola aktivitas ini mempengaruhi cara pandang manusia untuk menciptakan kantor kecil di rumah mereka. Usaha untuk menciptakan ruang kantor tersebut bukanlah tanpa sebab. Berdasarkan penelitian yang dilakukan oleh Jobstreet.com ternyata proses berpindahnya aktivitas bekerja dari kantor ke dalam hunian tidak bisa begitu saja berpindah. Banyak aspek yang melatarbelakangi kegiatan bekerja tidak bisa berjalan baik di dalam rumah. Beranjak dari permasalahan tersebut, maka timbulah sebuah pertanyaan tentang bagaimana merancang sebuah ruangan kerja yang terpisah dari aktivitas rumah yang mampu memberikan pengalaman bekerja dengan kualitas yang baik, sehingga kegiatan work from home dapat berjalan sebagaimana mestinya. Penelitian ini mengambil obyek pada sebuah hunian yang terletak di perumahan Cluster Naraya BSB City Semarang. Dimana perumahan ini memliki mayoritas penghuni berusia produktif yang disinyalir terdampak dengan kebijakan bekerja dari rumah. Arsitektur Biofilia menjadi teori utama dalam melihat sejauh mana perancangan pengembangan ruang kerja dapat memberikan dampak kualitas bekerja dari rumah yang baik.
\end{abstract}

Kata kunci: Arsitektur Biofilia, Hunian, Work from Home

\begin{abstract}
The Covid-19 pandemic requires humans for a certain period of time to avoid direct interaction between humans. To maintain work productivity, many steps are taken, including work from home activities. This change in activity patterns affects the way people perceive to create a small office in their home. Efforts to create office space is not without any reason. Based on research conducted by Jobstreet.com, it turns out that the process of moving work activities from the office to the residence cannot move easily. There are many aspects behind work activities that cannot work well at home. Moving on from these problems, a question arises about how to design a separate workspace from home activities that is able to provide a good quality of working experience, so that work from home activities can run as they should. This study takes the object of a residence located in the Naraya Cluster BSB City Semarang. Where this cluster has the majority of residents of productive age who are allegedly affected by the policy of working from home. Biophilic Architecture is the main theory in seeing how far the design of workspace development can have an impact on the quality of working from home.
\end{abstract}

Keywords: Biophilic Architecture, Residential, Work from Home 


\section{Pendahuluan}

\section{Latar Belakang}

Pandemi Covid-19 membawa perubahan yang siginifikan pada tatanan kehidupan manusia bekerja. Sejak awal bulan Maret tahun 2020, ketika diumumkan kasus pertama pasien Covid-19 mulailah begitu banyak kebijakan yang dikeluarkan oleh pemerintah. Salah satu kebijakan tersebut adalah kegiatan bekerja dari rumah atau work from home. Kebijakan ini diterapkan dengan maksud untuk menekan angka persebaran yang semakin tinggi terutama pada cluster perkantoran.

Berdasarkan data yang dihimpun melalui laman Jobstreet menunjukan bahwa selama tahun 2020 sudah ada 46\% pekerja di Indonesia diwajibkan untuk melakukan kegiatan bekerja dari rumah atau work from home akibat dari Pandemi Covid-19. Warna aktivitas dari bekerja di kantor dengan bekerja dari rumah tentu memiliki perbedaan yang signifikan. Dari $46 \%$ pekerja yang menerapkan proses bekerja dari rumah, penjelasan lebih rinci terkait detail aktivitas tersebut antara lain:

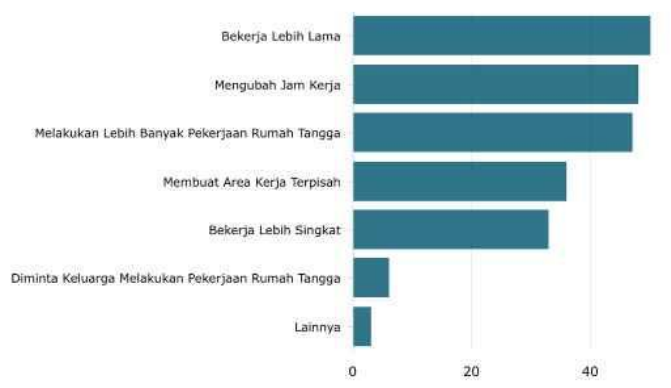

- $50 \%$ responden merasa durasi bekerja menjadi lebih panjang

- $48 \%$ responden harus mengubah waktu bekerja

- $47 \%$ responden mengaku lebih banyak melakukan pekerjaan rumah

- $36 \%$ responden harus membuat area kerja terpisah selama bekerja dari rumah

- 33\% responden merasa waktu bekerja di rumah lebih pendek

- $6 \%$ responden mengaku lebih sibuk diminta anggota keluarga untuk melakukan pekerjaan rumah tangga

- $3 \%$ responden memilih dampak lain ketika melakukan pekerjaan kantor dari rumah

Berdasarkan pada data di atas, artikel ini ingin mengulas lebih lanjut keterkaitannya dengan ilmu arsitektur. Dimana terdapat 36\% responden ternyata harus mengeluarkan usaha lebih untuk membuat area kerja terpisah di dalam rumah. Alasan kuat mengapa hal tersebut dapat terjadi adalah karena responden tersebut ingin mendapatkan pengalaman kualitas bekerja yang baik meskipun tidak di kantor.

Penggunaan ruang-ruang di dalam rumah memang tidak serta merta dapat dengan mudah dialihfungsikan menjadi ruang untuk bekerja. Ruang komunal di dalam rumah contohnya. Ruang ini paling sering digunakan para pekerja yang bekerja dari rumah untuk melaksanakan aktivitas kerja. Alhasil kualitas kerja tidak akan bisa maksimal. Hal ini dikarenakan ruang komunal di dalam rumah digunakan oleh banyak anggota keluarga dengan aktivitas yang beragam pula. Maka terdapat $47 \%$ responden yang mengatakan alokasi waktu lebih banyak digunakan untuk melakukan pekerjaan rumah, dan 6\% responden yang mengatakan terdapat permintaan dari anggota keluarga yang lain untuk melakukan pekerjaan rumah. Dengan kondisi tersebut, maka distraksi pekerjaan kantor yang mestinya dilakukan di rumah tidak akan berjalan dengan signifikan.

$36 \%$ responden yang mengatakan bahwa memerlukan tempat kerja khusus di dalam rumah ini ternyata memang berpengaruh pada evolusi desain hunian. Seperti berita yang dilansir oleh bisnis.com tanggal 25 April 2020 mengulas tentang pernyataan CEO Power Commerce Asia, Hadi Kuncoro yang mengatakan bahwa pola konsumsi masyarakat pada saat masa work from home atau bekerja dari rumah mulai berubah. Masyarakat kini sudah mulai berbelanja ke kategori gaya hidup dan furniture. Alih-alih ingin menciptakan kantor sendiri di rumah, supaya proses 
work from home bisa dilakukan dengan lebih nyaman dan produktif. Kegiatan berbelanja furniture atau perabot rumah tangga tersebut akan berlanjut dengan penataan ulang desain tata ruang dan perabot di dalam rumah. Bagi hunian yang terletak di kawasan real estate dan memiliki desain denah tipikal, hal ini dapat menjadi alasan yang kuat untuk melakukan pengembangan.

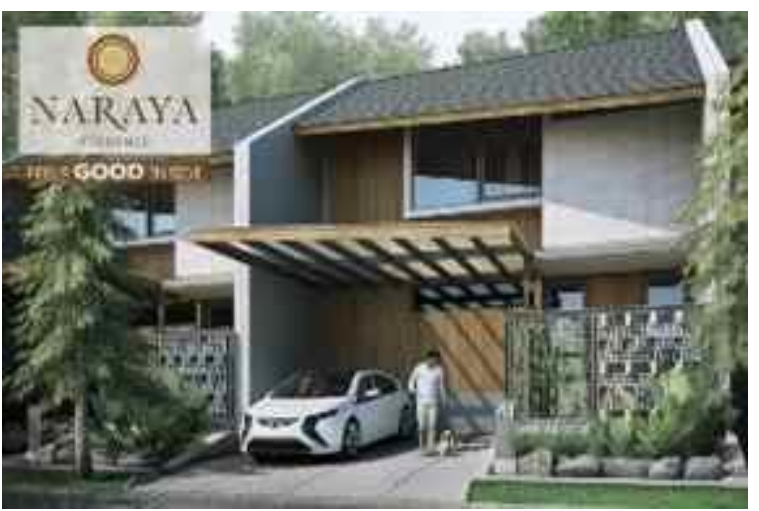

\section{Gambar 1. Fasad Hunian Naraya Sumber: bsbcity.com, 2015}

\section{Naraya BSB City Semarang}

Tulisan ini mengambil studi kasus pada desain hunian tipikal di Perumahan Cluster Naraya yang ada di Kawasan Bukit Semarang Baru (BSB) Kota Semarang. Objek tersebut diangkat menjadi lokasi penelitian karena denah desain tipikal dari cluster tersebut memiliki ruang sisa di bagian belakang bangunan yang masih dimungkinkan untuk dikembangkan dan menjadi rumah tumbuh.

Menurut Agusniansyah (2014) rumah tumbuh sendiri memiliki pengertian sebuah konsep yang diterapkan pada proses perencanaan hunian. Konsep pengembangan pelaksanaan dilakukan secara bertahap dengan maksud untuk mengakomodasi penambahan ruang sesuai dengan kebutuhan, keterbatasan anggaran dan luas lahan.

Alasan lain, cluster ini dikembangan mulai sekitar tahun 2017 dengan target pasar adalah para generasi dengan usia produktif. Terlihat dari konsep bangunan dan bentuk fasad bangunan yang cukup berbeda dengan cluster lain di kawasan Bukit Semarang Baru.
Dengan target pasar usia produktif, maka dapat disimpulkan bahwa penghuni Cluster Naraya juga merasakan imbas dari adanya peraturan untuk melaksanakan kegiatan Work from Home.

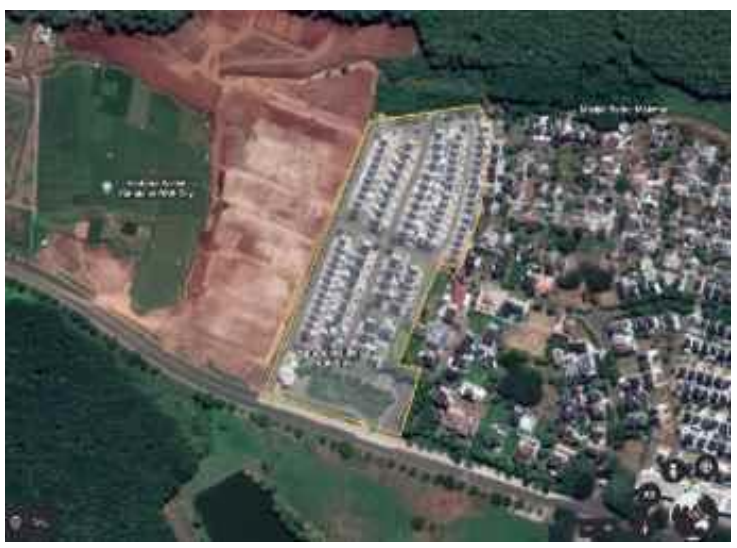

\section{Gambar 2. Peta Delineasi Cluster Naraya BSB City Semarang Sumber: earth.google, 2021}

\section{Rumusan Masalah}

Fokus kajian yang dapat
dideskripsikan menjadi rumusan inti
permasalahan pada artikel ini adalah:

- Sejauh mana efektifitas desain hunian tipikal pada kawasan perumahan dapat diadaptasikan menjadi rumah tumbuh?

- Bagaimana konsep Arsitektur Biofilia dapat meningkatkan kualitas aktivitas manusia? Khususnya pada masa work form home.

- Bagaimana penerapan kajian Arsitektur Biofilia pada pengembangan desain perencanaan ruang kerja sebagai bentuk usaha untuk mengakomodasi kegiatan work form home?

\section{Tujuan}

Tujuan utama yang menjadi latar belakang penulisan artikel ini adalah untuk mengetahui lebih dalam, bagaimana peranan elemen alam dalam mempengaruhi psikologi manusia. Psikologi manusia disini yang dimaksud adalah memberikan stimulus berupa keterlibatan alam dalam meningkatkan 
kualitas mutu, konsentrasi, serta minat dalam bekerja. Sehingga pada era kegiatan work from home ini, manusia dapat tetap bekerja secara produktif.

\section{Metode}

Dalam penelitian ini, metode yang digunakan adalah kualitatif deskriptif yang artinya penelitian memberikan gambaran secara cermat mengenai keadaan dan gejala yang terjadi (Koentjaraningrat, 1993; 89). Ciri-ciri dari penelitian dengan metode kualitatif menurut Bogden dan Biklen (1992; 27-29) antara lain:

- Qualitative research has the natural setting as the direct source of data, and the researcher is the key instrument.

- Qualitative research is descriptive.

- Qualitative researchers are concerned with process as well as product.

- Qualitative researchers tend to analyze their data inductively.

Metode kualitatif yang digunakan dalam penelitian ini akan membantu untuk menjawab permasalahan yang terfokus pada bagaimana kajian Arsitektur Biofilia diimplementasikan ke dalam sebuah desain pengembangan bangunan, dengan tujuan untuk meningkatkan kualitas kegiatan di dalam ruang pengembangan tersebut.

Pengamatan dilakukan pada sebuah objek hunian dengan desain awal tipikal, dimana pada area belakang rumah sudah mengalami pengembangan sesuai dengan kebutuhan pemilik.

Metode penelitian yang digunakan adalah studi kualitatif dengan pendekatan observasi, wawancara, dan literatur. Metode penelitian ini menggunakan metode rasionalis kualitatif. Metode rasionalis kualitatif memiliki ciri fenomena yang terjadi di lapangan merupakan data utama yang harus diamati oleh peneliti yang berperan sebagai instrument utama.

\section{Kajian Teori}

\section{Arsitektur Biofilia}

Hipotesis dasar dari Arsitektur Biofilia mengungkapkan bahwa pengguna bangunan ternyata tidak dengan mudah ingin untuk bekerja, bermain, makan, atau tidur. Mereka ingin pengalaman yang lebih, mereka ingin diinspirasi, dinyamankan, dan diyakinkan oleh suasana di sekitarnya. Hipothesis tersebut akan akurat ketika pemakai bangunan (manusia) dapat berafiliasi dan memberikan respon yang positif terhadap kinerja aktivitas manusia serta kesehatan dan juga keadaan emosional yang baik.

Menurut Almusaed (2011) arah orientasi baru daripada studi Arsitektur Biofilia bertujuan untuk menggerakan aksi manusia dalam arsitektur dan tanggung jawabnya terhadap alam. Hal ini dimaksudkan agar; hal-hal yang berkaitan antara alam dengan fisik menjadi lebih dari bersahabat; konsumsi energi bangunan yang diorganisir dengan sangat baik; manusia mengembangan sumber daya alami dengan sangat efektif; efek buruk dari pergantian iklim menjadi lebih rendah.

$$
\text { Arsitektur biofilia memiliki }
$$

perbedaan yang sangat siginifikan dengan arsitektur hijau. Dimana dalam arsitektur hijau, bangunan tradisional dalam memenuhi syarat menjadi bangunan hijau ketika diberikan sentuhan tanaman, teknologi dan sebagainya yang membuat bangunan tersebut menjadi bangunan hijau. Dalam arsitektur biofilia, bangunan harus dapat mengintepretasikan dalam bentuk dan gaya. Bangunan hijau adalah konstruksi yang dapat dibentuk dengan proses renovasi. Sedangkan arsitektur biofilia berusaha untuk memberikan bentuk yang mereduksi efek negatif dari iklim berskala mikro dan menambah kenyamanan fisik manusia untuk menciptakan hidup yang sehat. 
Interaksi Alami dan Fisik - Kerangka

\section{Arsitektur Biofilia}

Seringkali arsitek dalam menciptakan massa bangunan cenderung akan menghindari bentuk pejal (bulky). Bentuk-bentuk substraktif cenderung akan memberikan kesan yang ringan dan lebih harmonis dengan lingkungan sekitar. Langkah tersebut diambil bukan karena tanpa alasan, namun memang tepat jika bentuk substraktif lebih memberikan kesempatan pada bangunan untuk berkoneksi dengan lingkungan sekitarnya. Lubang, sela, ruang, bolong, adalah langkah yang bisa diterapkan untuk memberikan akses terciptanya harmoni antara bangunan dengan lingkungannya.

Ruang, lubang, sela ini merupakan ciri daripada alam. Berbeda dengan bentuk buatan yang lebih solid dan pejal. Interaksi antara alam dan fisik atau alam dengan buatan ini perlu menjadi sebuah sistem. Sistem yang diaplikasikan dengan tujuan untuk menciptakan harmoni dalam kerangka arsitektur biofilik.

Menurut Almusaed kerangka arsitektur bioflia selalu terdapat 3 obyek yang saling berinteraksi. Manusia, alam, dan bangunan. Dimana manusia menjadi pengguna daripada kedua obyek yang lain. Namun bukan pengguna yang pasif, pengguna yang aktif sehingga kedua obyek tersebut (alam dan bangunan) dapat berinteraksi dengan baik.

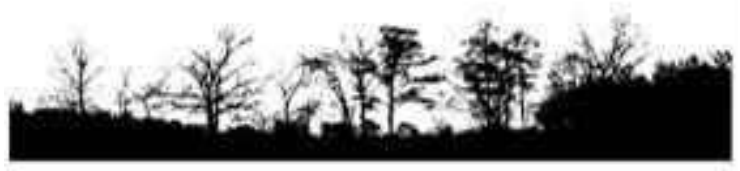

Gambar 3. Figur Alam

Sumber: Almusaed, 2011, 41

Gambaran figur alam yang lebih bersifat natural, luwes, lubang, dan bolong.

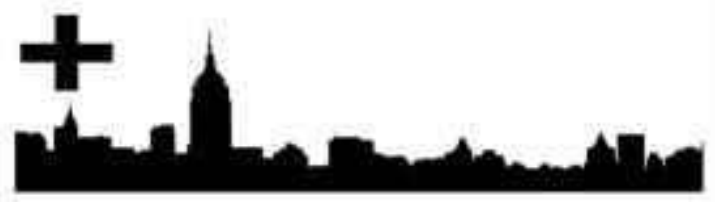

Gambar 4. Figur Fisik

Sumber: Almusaed, 2011, 41
Gambaran figur lingkungan buatan yang lebih bersifat pejal, penuh.

Dalam kehadirannya manusia ingin selalu memberikan peran. Termasuk dalam membuat interaksi yang lebih harmonis antara lingkungan buatan dan lingkungan fisik. Proses kehadiran manusia yang secara aktif ingin mengkolaborasikan kehadiran bangunan dalam habitat aslinya dapat dideskripsikan melalui gambar berikut:

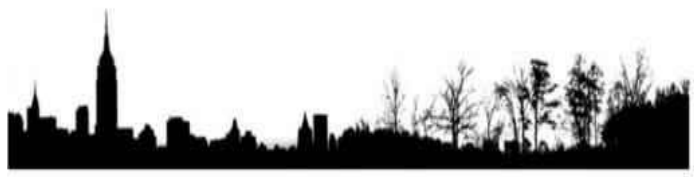

Gambar 5. Persinggungan Elemen Fisik dan Alami

Sumber: Almusaed, 2011, 41

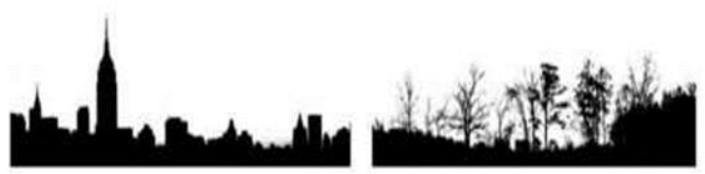

Gambar 6. Hubungan Antar Tepi Elemen Fisik dan Alami

Sumber: Almusaed, 2011, 41
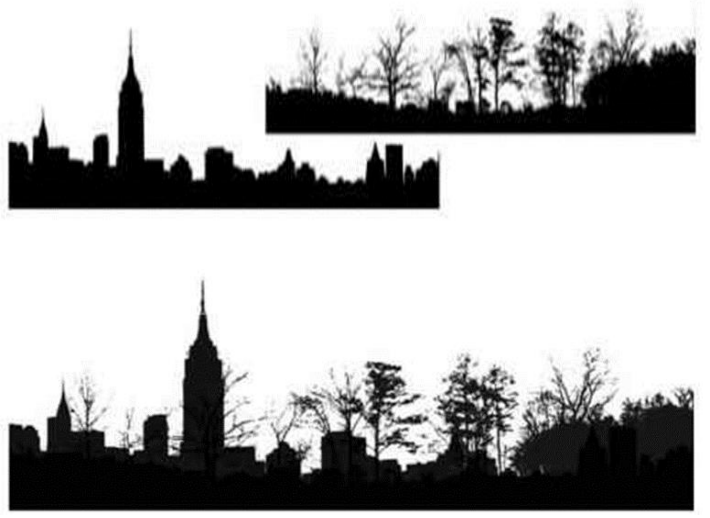

Gambar 7. Proses Sinergi Antara Elemen Fisik dan Alami Sumber: Almusaed, 2011, 42

1. Awal mula antara bangunan (bangunan fisik) dengan lingkungan alami terpisah dan memiliki jarak. Jarak tersebut dapat diartikan sebagai media perantara atau peralihan kegiatan manusia dari ruang luar menuju ruang dalam. Media tersebut dapat berupa jalan, pedestrian, saluran kota dan sebagainya. 
2. Tahap berikutnya, manusia mencoba untuk menarik alam lebih dekat dengan bangunan. Pada tahap ini sudah tidak ada lagi media atau perantara antara bangunan dengan alam. Adanya halaman atau ruang terbuka di depan rumah atau di belakang rumah, adalah hasil dari pemikiran manusia pada tahap ini.

3. Arsitektur biofilia adalah sebuah inovasi dalam ilmu arsitektur. Dimana alam, kehidupan, dan bangunan bergabung untuk menciptakakan sebuah habitat baru untuk memberikan kualitas, kepuasan dalam kehidupan manusia walaupun tetap memperhatikan dan menghormati keberadaan keduanya (manusia dan alam). Pada tahap ini alam dan bangunan bergabung menjadi satu, menciptakan sebuah harmoni yang estetis. Penerapan arsitektur biofilia sering diartikan dengan mengimplementasikan kehadiran alam di dalam / di tengah massa bangunan. Pada gambar di atas dapat dilihat bahwa kehadiran alam dan bangunan direspon dengan sebuah langkah bijak dengan memadupadankan keduanya.

Alam sebagai bagian dari konsep arsitektur Arsitektur biofilia memandang kepentingan yang setara antara bangunan dengan alam. Pada hakikatnya karya arsitektur mestinya dapat menjadi wadah kegiatan atau aktivitas bagi penggunanya. Dalam menciptakan wadah kegiatan tersebut, arsitektur biofilia selalu mempertimbangkan kelangsungan kehidupan alam dalam konsep perancangan arsitektur. Hal ini tidak lain karena kembali pada aspek psikologis manusia yang selalu merasa nyaman bila beraktivitas berdekatan dengan alam.

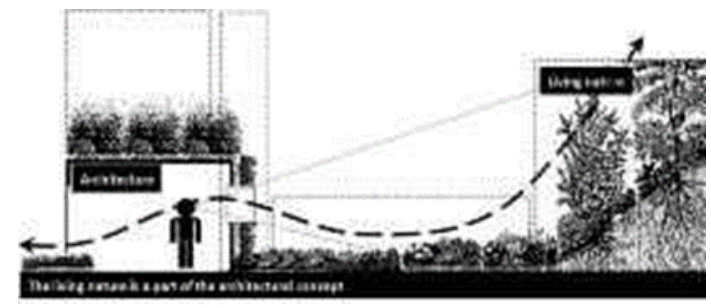

Gambar 7. Hubungan Alam Bangunan Manusia

Sumber: Almusaed, 2011, 42
Pada gambar di atas dapat dipahami bahwa kehadiran bangunan tidak serta merta merusak alam. Maka deskripsi daripada keadaan eksisting tapak sangatlah penting untuk dijadikan dasar pengembangan konsep selanjutnya. Semakin kuat aspek alam eksisting pada tapak yang dapat dideskripsikan oleh arsitek, maka akan semakin tajam arsitektur biofilia dapat menjadi konsep perancangan bangunan tersebut.

\section{Arsitektur Biofilia dan Arsitektur Hijau}

Pemahaman tentang kedua teori arsitektur ini perlu diketahui secara komprehensif. Walaupun memiliki landasan orientasi yang sama yaitu berorientasi ke alam, namun keduanya memiliki beberapa perbedaan yang signifikan.

\section{Tipologi Psikologi dalam Arsitektur Biofilia}

Menurut Laersen

pandangan ilmu psikologi dalam arsitektur biofilia, terdapat interaksi dan relasi antara manusia dan lingkungan. Dimana manusia adalah subyek yang aktif, sedangkan alam menjadi wadah daripada aktivitas manusia yang aktif. Manusia ingin mengambil peran, tidak hanya pengguna namun juga memberikan arti pada ruang hidup. Ruang (space) disini tidak hanya diartikan sebagai sesuatu yang pasif, namun hidup. Terdapat interaksi antara keduanya.

Keadaan prilaku manusia yang dipengaruhi oleh psikologinya dapat dirumuskan menjadi:

$$
\begin{aligned}
& B=\text { Behaviour } \\
& \mathrm{H}=\text { Human } \\
& \mathrm{E}=\text { Environment }
\end{aligned}
$$

$$
B=F(H E)
$$

\section{Pola Arsitektur Biofilia}

Menurut Browning (2015) teori arsitektur biofilia dapat diintisarikan kedalam 14 poin yang menitikberatkan sejauh mana sebuah desain arsitektur mengimplementasikan teori tersebut. 14 poin tersebut antara lain: 


\section{Pola Koneksi Alam Dalam Ruang}

Pola ini memiliki maksud untuk memberikan kehadiran alam dalam ruang secara langsung. Pengaplikasian elemen alam seperti: tanaman hidup, air, binatang, termasuk suara serta aroma akan menambahkan pengalaman kualitas panca indera manusia pada ruang yang berbasis pada detail identitas alam.

1. Koneksi visual dengan alam (visual connection with nature)

Poin ini menitikberatkan pada pengalaman pengguna bangunan secara visual dapat melihat elemen alam, serta sebuah sistem kehidupan yang bersifat alami. Misalnya pengaplikasian lanskap dengan berbagai macam tanaman, kolam tempat hidup binatang air, dan sebagainya.

2. Koneksi non-visual dengan alam (nonvisual connection with nature)

Hubungan antara pengguna bangunan dengan alam tidak hanya bersifat secara visual. Indera manusia yang lain seperti pengalaman audial dengan adanya suara air mengalir atau daun yang berserakan, serta pengaplikasian material alami yang akan memberikan pengalaman tersendiri pada indera peraba, merupakan langkah-langkah yang dapat diterapkan untuk mendapatkan pengalaman berhubungan dengan alam.

3. Stimulus sensorik tidak berirama (nonrhythmic sensory stimuli)

Hubungan dengan alam yang bersifat sekejap, dapat dianalisis namun tidak dapat diprediksi secara tepat.

4. Variabel suhu udara dan gerak angin (thermal \& airflow variability)

Pertimbangan desain yang memperhatikan gerak udara supaya suhu, kelembapan, dapat terjaga dengan baik akan mampu memberikan pengalaman alami yang maksimal.
5. Kehadiran elemen air (presence of water)

Tanpa disadari, mempertimbangkan elemen air dalam bangunan dapat secara signifikan memberikan pengalaman alami yang cukup berkesan.

6. Pencahayaan dinamis dan menyebar (Dynamic \& Diffuse Light)

Pemanfaatan arah cahaya alami dengan intensitas bervariasi serta bergerak secara dinamis mampu memberikan pengalaman alami yang menarik.

7. Hubungan dengan elemen alami (Connection with Natural Systems)

Ekosistem alami yang sehat akan mengalami sebuah proses perubahan (musiman). Hal ini juga dapat memberikan pengalaman menarik.

\section{Analogi Alami}

Analogi alami memiliki karakteristik untuk menggunakan elemen-elemen organik, artificial yang dapat merepresentasikan kehadiran alam. Obyek, warna, material, bentuk yang terlahir dalam karya seni, lukisan, ornamen, dekorasi dapat menjadi elemen pendukung. Karakter alami lebih berfokus pada bentuk, mimikri dari elemen-elemen alam seperti daun, cangkang, walaupun buatan namun tetap bisa menjadi arti kehadiran elemen alam pada ruang.

Tidak hanya elemen, namun material bangunan yang berorientasi pada representasi alam juga termasuk pada fokus kajian ini. Wood plank contohnya, walaupun terbuat dari material non alami (bukan kayu) namun dapat menghadirkan kesan alam. Fokus kajian analogi alami dapat dikerucutkan menjadi beberapa poin antara lain:

1. Bentuk dan pola biomorfik (Biomorphic Forms \& Patterns)

Referensi simbolis yang dapat merepresentasikan pola, tekstur, atau tatanan lain yang terdapat di alam.

2. Hubungan material dengan alam (Material Connection with Nature)

Tesa Arsitektur Volume 19 | Nomor 1 | 2021 
Material dan elemen bangunan yang paling tidak proses pembentukannya berangkat dari alam. Kajian ini diharapkan dapat merefleksikan lokalitas ekologi dan membangun keterikatan sebuah lokasi.

3. Kompleksitas dan keteraturan (Complexity \& Order)

Informasi yang didapat oleh kemampuan sensorik yang kompleks, menganut pengertian spasial serupa dengan yang dapat dijumpai di alam.

\section{Pola Alami Ruang}

Kajian ini memiliki fokus pada pembentukan konfigurasi ruang alam. Hal ini melibatkan inisiasi dan keinginan perancang dalam melihat lingkungan sekitar. Beberapa hal yang dapat dipertimbangkan ketika ingin mempelajari pola alami ruang secara lebih mendalam antara lain:

\section{Prospek (Prospek)}

Sebuah sudut pandang dari kejauhan, dengan tujuan untuk pengawasan dan perencanaan.

2. Tempat perlindungan (Refuge)

Sebuah tempat untuk menarik diri dari kondisi lingkungan setempat, atau dari aktivitas inti yang terjadi, dimana individu dapat terlindungi.

3. Misteri (Mystery)

Sebuah ruang dengan kondisi misteri yang baik memiliki rasa antisipasi, atau sifat yang menggoda, menawarkan indera semacam penolakan dan akan memaksa seseorang untuk menyelidiki lebih lanjut ruang tersebut

4. Resiko (Risk)

Sebuah langkah yang bersifat ancaman, dan dapat diidentifikasi dengan perlindungan yang memadai spesifikasi luas tanah tipikal sebesar $150 \mathrm{~m} 2$ dan luas bangunan $80 \mathrm{~m} 2$. Luas bangunan sebesar $80 \mathrm{~m} 2$ tersebut terbagi menjadi 2 lantai, dengan total luas masingmasing lantai sebesar 40m2. Perbandingan luas lahan 150m2 dan luas lantai dasar 40m2 menjadikan hunian ini masih sangat dimungkinkan untuk dilakukan pengembangan. Pada gambar di bawah terdapat obyek berbentuk persegi panjang berwarna merah yang merupakan area halaman belakang yang menjadi ruang pengembangan.

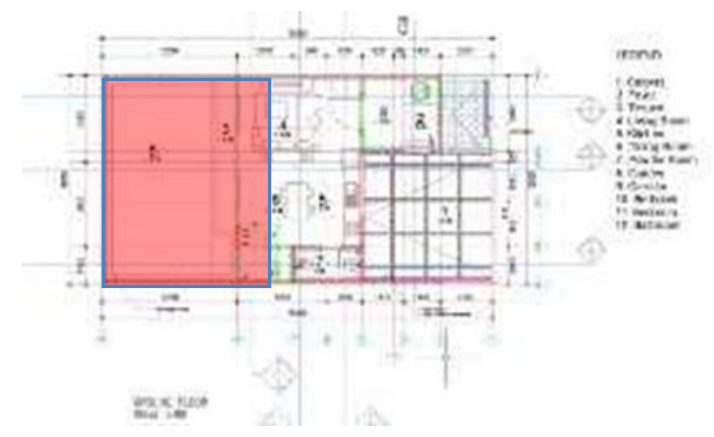

Gambar 8. Denah Tipikal Hunian Sumber: Dokumentasi Pribadi, 2017

Hunian yang menjadi obyek penelitian pada penelitian ini sudah mengalami pengembangan desain. Pemilik melakukan pengembangan pada halaman belakang bangunan dengan tujuan untuk mengakomodasi kebutuhan ruang kerja pada masa Pandemi Covid-19. Sesuai dengan keinginan pemilik, pengembangan ruang kerja pada halaman belakang mengadopsi konsep Arsitektur Biofilia. Konsep ini digunakan dengan tujuan supaya pengguna ruang kerja tersebut dapat merasakan pengalaman kerja dengan suasana alam yang mendukung. Sesuai dengan kaidah teori Arsitektur Biofilia, diharapkan beberapa eleman alam yang disematkan pada konsep pengembangan ruang tersebut mampu membantu bahkan meningkatkan kualitas kegiatan bekerja dari rumah.

\section{Pembahasan}

Gambar di bawah merupakan denah tipikal hunian tipe Inari pada Cluster Naraya BSB Semarang. Dengan 


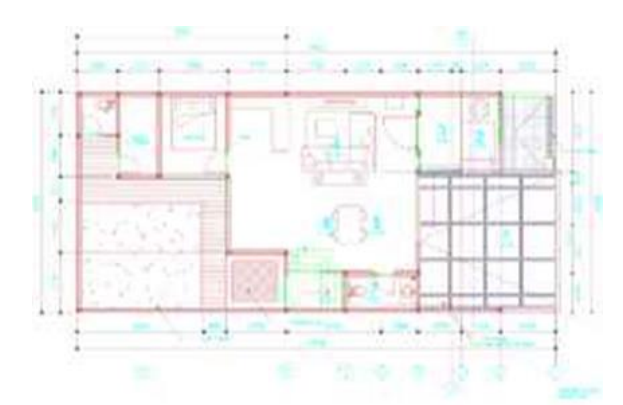

Gambar 9. Denah Renovasi Hunian Sumber: Dokumentasi Pribadi, 2017

Proses pengembangan hunian yang menjadi obyek pada tulisan ini dilaksanakan sebanyak 2 tahap. Seperti halnya konsep daripada rumah tumbuh, hunian ini juga mengalami pengembangan sesuai dengan kebutuhan pemilik bangunan. Desain pengembangan pertama dilakukan seperti pada gambar di atas. Pengembangan pertama dilakukan untuk mengakomodasi kebutuhan tambahan ruang tidur untuk anggota keluarga. Dengan luasan awal 80m2 hanya terdapat 2 kamar tidur, maka diperlukan tambahan kamar tidur. Pada pengembangan pertama, pemilik bangunan tetap memiliki konsep untuk selalu berorientasi ke alam. Hal tersebut dapat dilihat dengan desain kamar tidur tambahan yang memiliki orientasi menghadap ke arah taman atau ruang terbuka.

Setelah pengembangan tahap 1 selesai, dilakukan pengembangan tahap 2 . Pengembangan tahap 2 dilakukan untuk mengakomodasi kebutuhan ruang kerja pada masa work from home akibat Pandemi Covid-19.

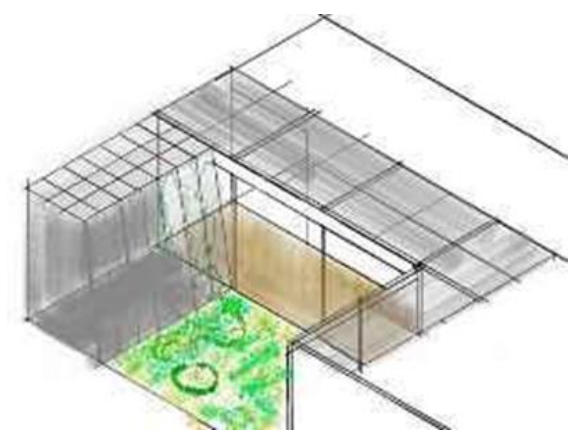

Gambar 10. Sketsa Desain
Pengembangan

Sumber: Dokumentasi Pribadi, 2020

TERAKREDITASI : 36/E/KPT/2019

ISSN cetak 1410-6094 | ISSN online 2460-6367
Gambar di atas adalah sketsa desain pengembangan tahap 2. Dimana konsep desain Arsitektur Biofilia lebih dapat dirasakan. Desain pengembangan ruang kerja pada gambar di atas dapat dilihat pada bagian yang diekspose dengan bidang persegi panjang. Dapat dilihat pada sketsa desain tersebut bahwa ruang kerja memiliki orientasi pandangan juga menghadap ke area taman atau ruang terbuka.

\section{Parameter Pengamatan}

Untuk melihat sejauh mana pengembangan desain ruang kerja yang mampu meningkatkan kualitas work from home dengan bantuan elemen-elemen alam, maka digunakanlah parameter ukur berdasar pada Teori Arsitektur Biofilia. Parameter tersebut digunakan untuk melihat bagaimana penerapan beberapa poin yang menjadi intisari dari teori Arsitektur Biofilia. Poin tersebut antara lain:

\section{Alam Dalam Ruang}

- Koneksi Visual dengan Alam

- Koneksi Non-Visual dengan Alam

- Variabel Suhu Udara \& Gerak Angin

- Kehadiran Elemen Air

- Pencahayaan Dinamis dan Menyebar

- Hubungan Dengan Sistem Alam

Analogi Alam

- Bentuk - Pola Biomorfik

- Material Alami

- Kompleksitas dan Keteraturan

Sifat Alami Ruang

- Misteri

\section{Analisis}

- Koneksi Visual dengan Alam

Terdapat hubungan visual dengan eleman alam yang baik pada desain pengembangan ruang kerja di hunian yang menjadi obyek penelitian. Hal ini dapat dilihat dari penetapan orientasi ruang kerja yang langsung menghadap ke ruang terbuka, dimana pada ruang terbuka tersebut terdapat unsur-unsur kehidupan alam serta proses alami berupa

Tesa Arsitektur Volume 19 | Nomor 1 | 2021 
penanaman beberapa jenis vegetasi. Pengalaman visual melihat secara langsung beberapa tanaman tumbuh, bergerak karena angin, bahkan mengeluarkan bunyi ketika terkena air hujan menjadikan pengalaman yang sangat baik berkat pengaplikasikan konsep Koneksi Visual dengan Alam.

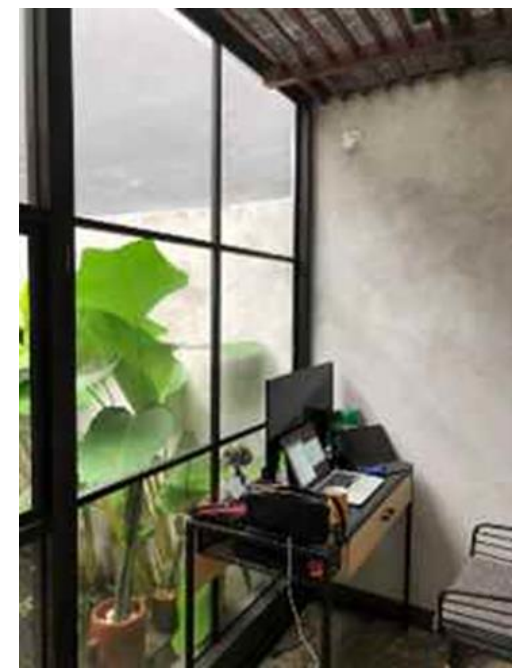

Gambar 11. Orientasi Ruang Sumber: Dokumentasi Pribadi, 2020

Pada gambar di atas dapat dilihat bagaimana tatanan orientasi ruang serta perabot yang sengaja menghadap ke arah ruang terbuka dimana terdapat beberapa jenis tanaman tumbuh dan berdinamika secara alami.

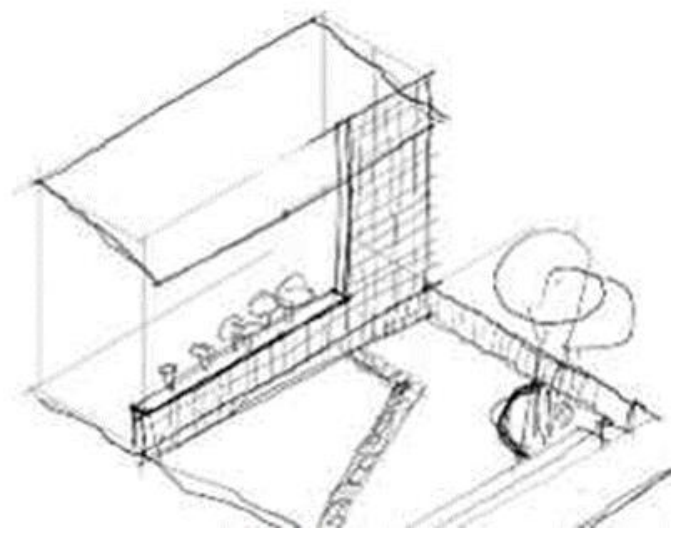

Gambar 12. Sketsa Pengembangan Sumber: Dokumentasi Pribadi, 2020

Pengaplikasian konsep Koneksi Visual dengan Alam sudah direncanakan sejak awal, dimana ruangan kerja harus menghadap ke alam terbuka. Alasan utama adalah supaya pengalaman kerja dapat terbangun dengan baik adanya hubungan visual dengan elemen-elemen alami, yakni tumbuhan, langit, serta fenomena cuaca yang sering berubah.

- Koneksi Non-Visual dengan Alam

Hubungan non-visual dengan alam juga diemplementasikan pada rancangan pengembangan ruang kerja. Hal ini terlihat melalui beberapa penerapan elemen desain yang memberikan stimulus tidak hanya pada indera penglihatan (visual), melainkan pada indera peraba, indera penciuman, serta indera pendengaran.

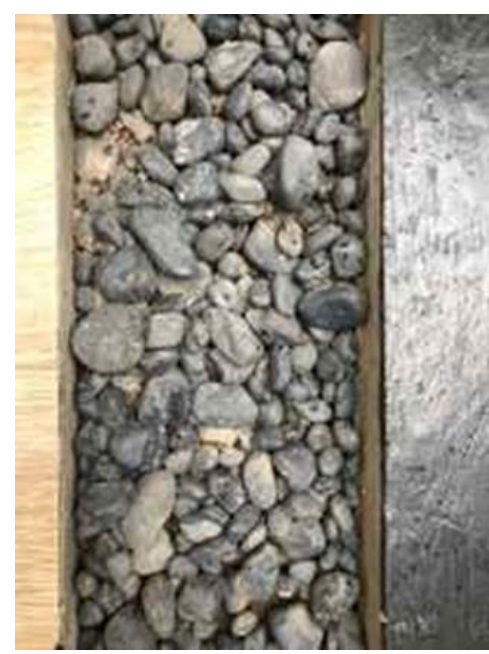

\section{Gambar 13. Material Batu Coral Sumber: Dokumentasi Pribadi, 2020}

Penerapan batu coral di sekeliling area pengembangan ruang kerja.

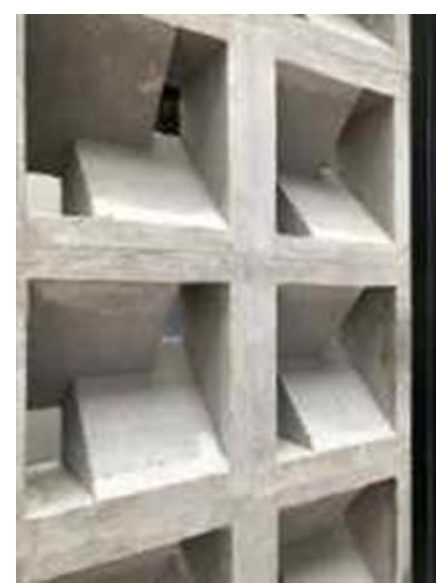

Gambar 14. Material Roster Mentah Sumber: Dokumentasi Pribadi, 2020 
Penerapan raw material atau material mentah berupa lubang dinding atau Roster yang terbuat dari pasir dan semen yang dipadatkan. Roster yang menjadi elemen dinding sengaja dipertahankan mentah tanpa adanya sentuhan cat atau coating yang biasanya digunakan untuk finishing.

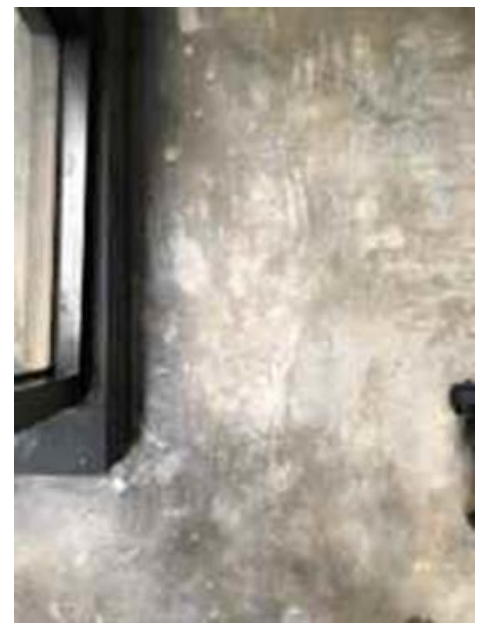

Gambar 14. Material Beton Ekspose Sumber: Dokumentasi Pribadi, 2020

Elemen lantai pada area pengembangan ruang kerja juga sengaja dibuat mentah. Beton ekspose menjadi pilihan untuk mempertahankan karakter dan konsep interior yang asli dan alami.

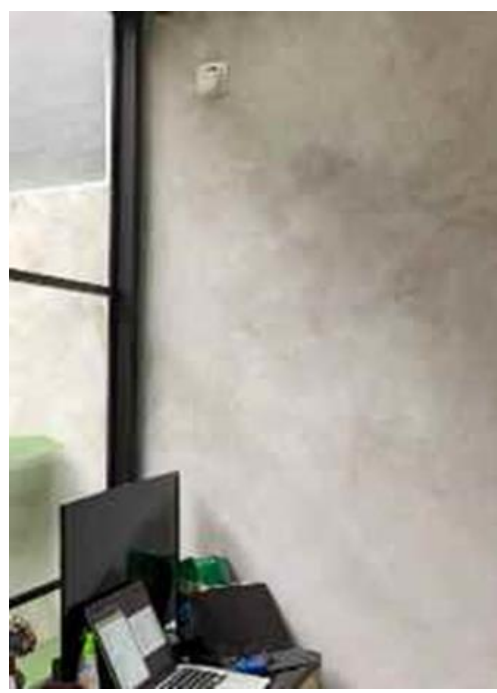

Gambar 15. Material Beton Ekspose Sumber: Dokumentasi Pribadi, 2020
Untuk mempertahankan konsep asli dan alami material dinding juga menggunakan beton ekspose.

Usaha untuk mempertahankan material supaya tetap mentah dan asli memiliki tujuan untuk memberikan pengalaman pada indera peraba. Dimana ketika pengguna bangunan permukaan kulitnya menyentuh atau bersinggungan dengan elemen bangunan di atas akan merasakan kesan yang kasar dan mentah. Kesan tersebut merupakan sifat dasar dari elemen alam.

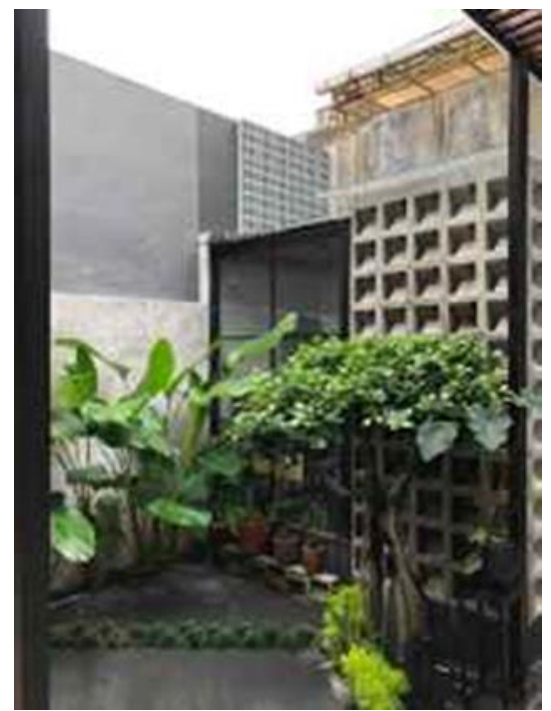

\section{Gambar 16. Vegetasi Sekeliling Ruang} Sumber: Dokumentasi Pribadi, 2020

Pengaplikasian beberapa jenis tanaman yang langsung bersinggungan dengan area pengembangan ruang kerja juga dimaksudkan untuk memberikan pengalaman pada indera penciuman. Beberapa karakter tanaman yang diaplikasikan memiliki karakter bau yang khas. Pengalaman indera penciuman ini akan semakin terstimulus dengan baik ketika kelompok tanaman tersebut tersiram oleh air hujan. Bau yang khas akan timbul dan memberikan pengalaman serta relaksasi yang baik untuk mendukung aktivitas kerja. 


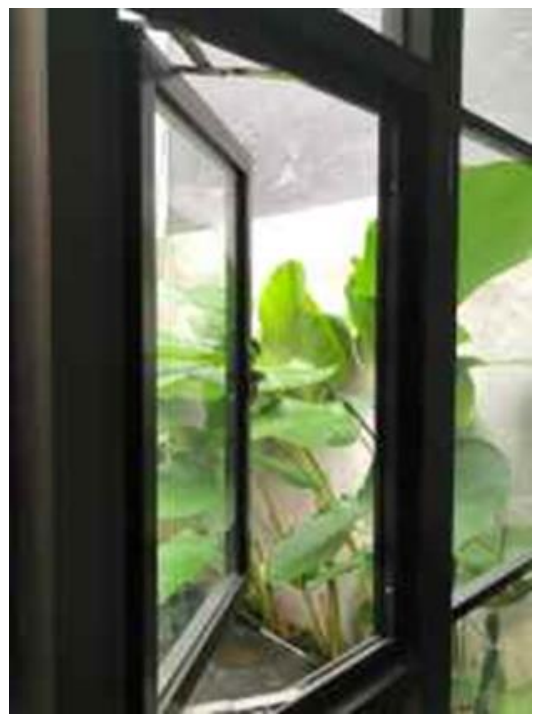

Gambar 16. Jendela Sumber: Dokumentasi Pribadi, 2020

Pengalaman indera penciuman tersebut akan terbangun dengan sangat baik berkat pengaplikasian sirkulasi udara berupa jendela yang ada pada ruang kerja.

Tidak hanya indera penciuman, pengalaman indera pendengaran pun juga terakomodasi dengan sangat baik berkat adanya sirkulasi ini. Suara gemericik air hujan, gesekan daun pisang yang terjadi akibat adanya gerakan angin, dapat terdengar dengan sangat jelas. Stimulus indera pendengaran terbangun tidak hanya karena jendela, namun juga karena dinding ruangan yang terbuat dari Roster. Dimana Roster memiliki karakteristik yang berlubang, sehingga mampu juga untuk menghantarkan rambatan suara.

\section{- Variabel Suhu Udara \& Gerak Angin}

Poin variabel suhu udara dan gerak angin juga dapat terakomodasi pada desain rancangan ruang kerja ini. Gerak angin atau sirkulasi udara dapat berjalan dengan lancar berkat pengaplikasian Roster serta bukaan yang ada pada ruang kerja.

Walaupun gerak angin dapat terakomodasi dengan baik, namun suhu pengkondisian suhu udara perlu mendapatkan perencanaan lebih lanjut. Hal ini disebabkan material yang menjadi atap pada ruang kerja ini adalah kaca. Kaca diaplikasikan untuk mendukung pencahayaan alami. Pengaplikasian kaca ternyata memberikan dampak kurang baik ketika musim kemarau. Suhu dalam ruangan akan menjadi sangat tinggi, sehingga diperlukan lapisan penutup atap yaitu Paranet. Paranet digunakan untuk mereduksi sengatan panas sinar matahari supaya suhu udara di dalam ruangan dapat dikondisikan dengan lebih baik.

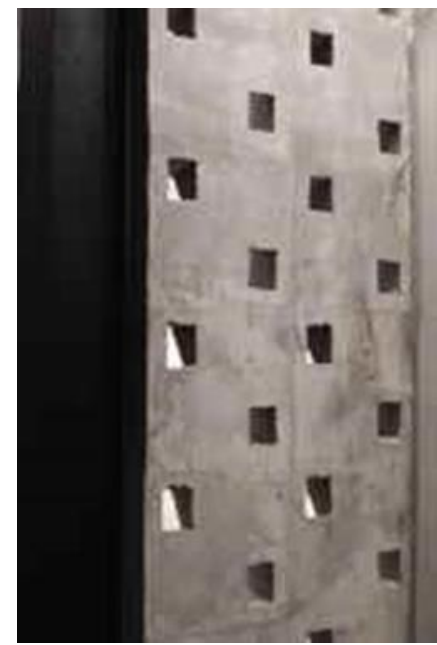

Gambar 17. Lubang Roster Sumber: Dokumentasi Pribadi, 2020

$$
\text { Pengaplikasian Roster pada }
$$
dinding ruangan. Lubang Roster yang tergolong kecil namun banyak mengakibatkan udara tetap bisa bergerak di dalam ruangan, namun tidak signifikan untuk mengkondisikan suhu udara.

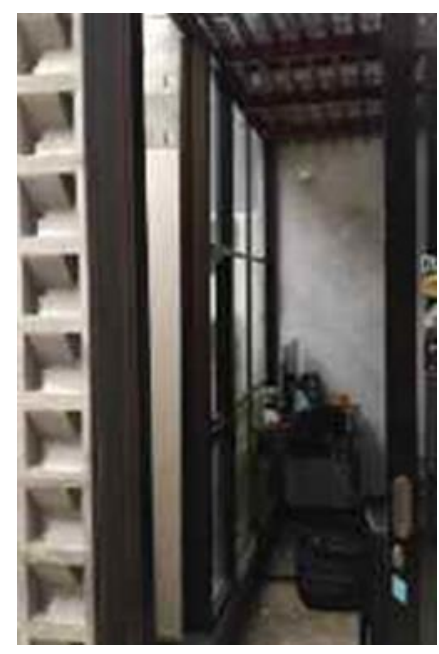

Gambar 18. Bukaan Ruang Sumber: Dokumentasi Pribadi, 2020 
Bukaan pada ruangan yang sekaligus menjadi pintu akses juga membantu terjadinya gerak angin.

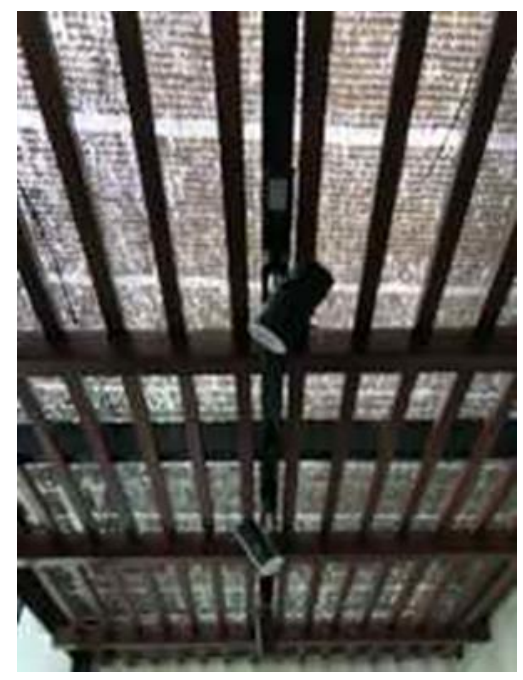

Gambar 19. Konstruksi Atap Sumber: Dokumentasi Pribadi, 2020

Pengaplikasian material berupa Paranet untuk menyaring panas sinar matahari. Dengan paranet, sinar matahari masih dapat masuk, namun panas dapat tereduksi hingga $80 \%$. Pengaplikasian Paranet dimaksudkan untuk pengkondisian suhu udara dalam ruang yang cenderung tinggi di musim kemarau.

- Pencahayaan Dinamis dan Menyebar

Aspek pencahayaan juga dapat terakomodasi dengan baik pada pengembangan ruang kerja. Penggunaan kaca sebagai material atap memberikan pengalaman pencahayaan yang dinamis. Ruang kerja yang menerima cahaya matahari, akan mengalami variasi arah datangnya cahaya. Mulai pagi hingga sore hari dan juga titik sudut datangnya sinar matahari yang bervariasi setiap bulan.

- $\begin{aligned} & \text { Hubungan Dengan Sistem Alam } \\ & \text { (lumut) }\end{aligned}$

Tanpa disadari, pengguna ruang kerja akan juga mengalami hubungan dengan sistem alam karena pengaplikasian konsep Arsitektur Biofilia ini. Hal ini dapat dilihat dari fenomena pertumbuhan tanaman yang dapat dilihat langsung oleh pengguna ruangan. Dimana orientasi ruang yang langsung menghadap ke berbagai jenis tanaman yang ada.

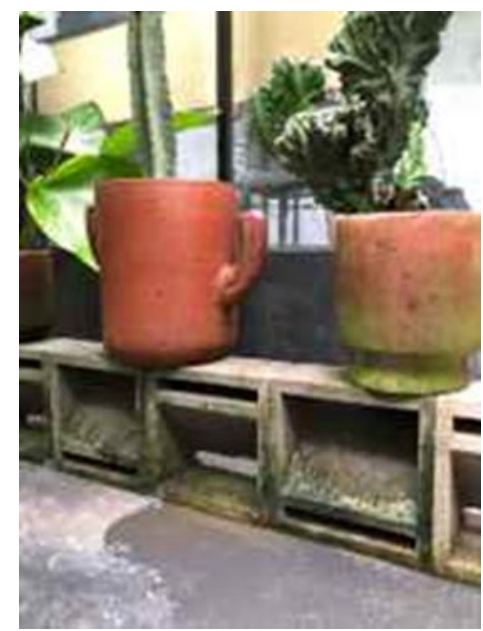

\section{Gambar 20. Lumut Pada Material Roster Sumber: Dokumentasi Pribadi, 2020}

\begin{abstract}
Hal lain yang dapat merepresentasikan pengalaman perubahan yang diakibatkan oleh faktor alam adalah perubahan material. Dimana beberapa elemen bangunan yang bersifat alami, akan dengan mudah menjadi media bagi alam untuk tumbuh. Contohnya pada Roster yang kini mulai ditumbuhi lumut. Perubahan ini memberi kesan dan pengalaman tersendiri, dimana pengguna merasa semakin dekat dengan alam ketika bekerja.
\end{abstract}

\section{Analogi Alam}

- Bentuk - Pola Biomorfik; Kompleksitas dan Keteraturan

Beberapa elemen bangunan yang dapat menganalogikan kehadiran alam melalui bentuk, pola, kompleksitas, dan keteraturan pada pengembangan ruang kerja adalah bentuk dan tatanan daripada Roster. Roster sebagai elemen utama pembentuk dinding memilki bentuk yang khusus dan ritmis. Seperti layaknya sifat alami elemen alam yang memiliki kompleksitas dan keteraturan. Pengaplikasian Roster yang memiliki bentuk teratir dan kompleks mampu memperkuat pengalaman kehadiran alam pada ruang kerja. 


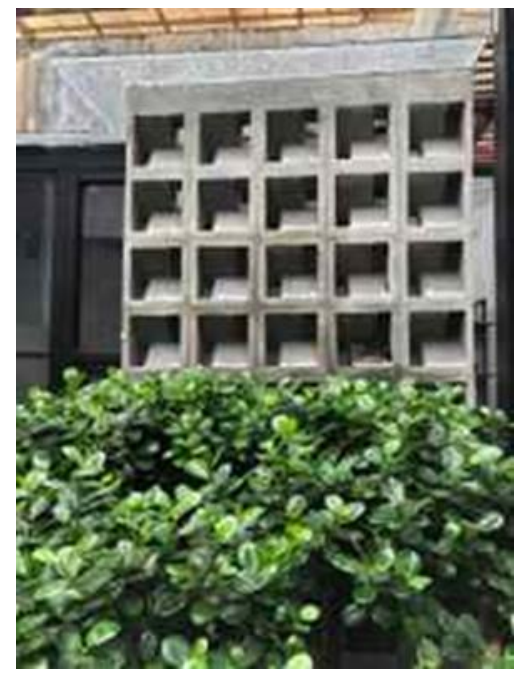

Gambar 21. Bentuk Roster

Sumber: Dokumentasi Pribadi, 2020

- Material Alami

Beberapa material alami digunakan pada pengembangan ruang kerja. Hal ini dimaksudkan untuk memperkuat kesan lingkungan lokal, dan memberikan rasa yang berbeda dengan area dalam hunian.

Pengaplikasian material alami sekaligus sengaja digunakan sebagai elemen estetis. Seperti kayu yang digunakan sebagai elemen estetis plafond dan sebagai tundan (rak) yang menjadi tempat untuk meletakan hiasan dinding. Selain kayu, Roster sendiri juga menjadi material alami yang digunakan sebagai elemen pembentuk dinding sekaligus elemen estetis.

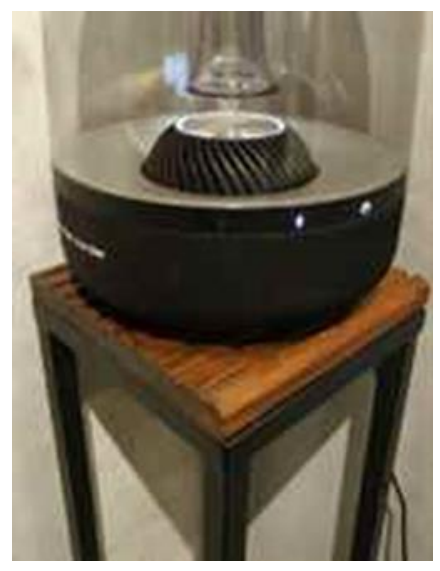

Gambar 22. Material Kayu

Sumber: Dokumentasi Pribadi, 2020

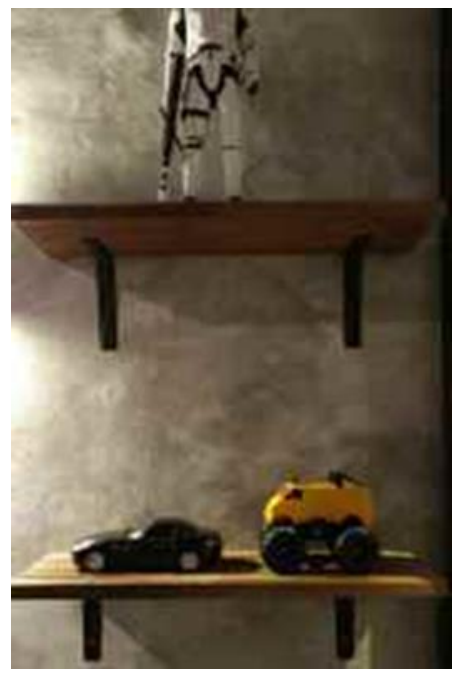

Gambar 23. Material Kayu Sumber: Dokumentasi Pribadi, 2020

Beberapa pengaplikasian material kayu sebagai material alami yang menjadi penguat kehadiran alam dalam ruang kerja.

Sifat Alami Ruang

- Misteri

Misteri memiliki maksud untuk memberikan kesan yang menggoda, dimana indera manusia akan semakin penasaran untuk menelusuri secara lebih dalam, walaupun secara bersamaan ada perasaan menolak.

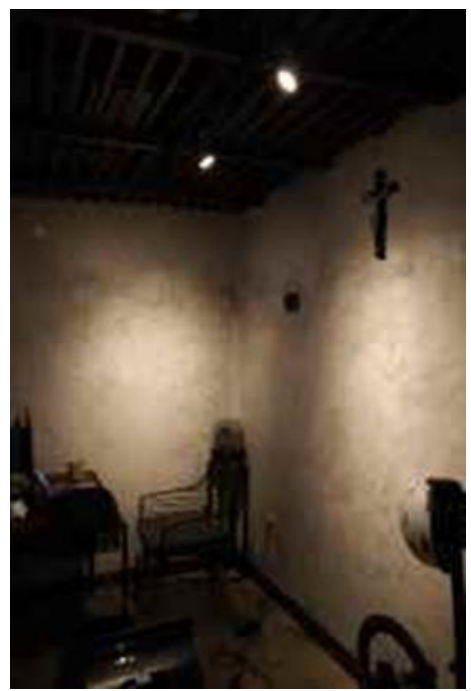

Gambar 24. Permainan Lampu

Sumber: Dokumentasi Pribadi, 2020 


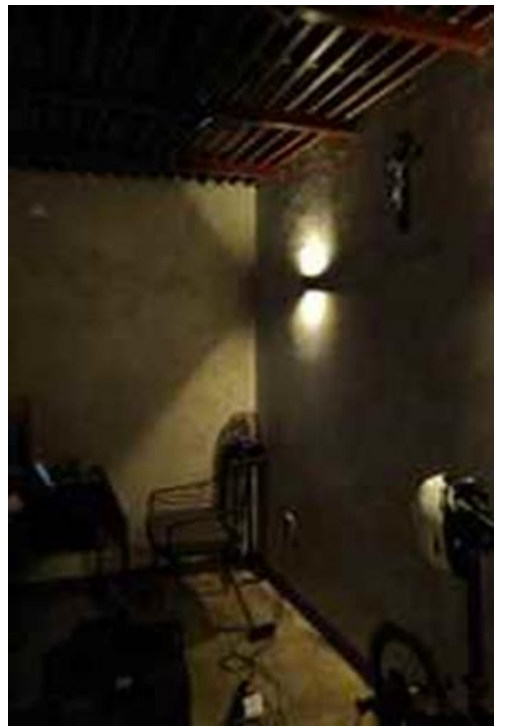

Gambar 25. Permainan Lampu Sumber: Dokumentasi Pribadi, 2020

Kesan misteri dalam ruang kerja tercipta melalui permainan pencahayaan buatan. Jenis lampu sengaja dipilih dengan kategori warna hangat, dan mengaplikasikan jenis lampu yang memiliki arah pendar khusus. Dengan permainan teknik pencahayaan buatan yang tepat, maka kesan misteri pada sebuah ruang dapat tercapai.

\section{Kesimpulan dan Saran}

\section{Kesimpulan}

Berdasarkan analisis di atas dapat dideskripsikan beberapa poin kesimpulan yang menjadi hasil daripada artikel ini.

Pengembangan ruang kerja pada hunian tipe Inari Cluster Naraya di kawasan BSB Semarang sudah menerapkan beberapa poin dalam kajian Arsitektur Biofilia. Penerapan kajian Arsitektur Biofilia yang kemudian ditarik menjadi konsep bangunan ini bertujuan untuk mendukung kualitas pengalaman aktivitas bekerja di dalam hunian pada masa work from home akibat Pandemi Covid-19.

Arsitek perancang memandang bahwa sangat penting menjembatani hubungan antara aspek alam dengan elemen fisik bangunan supaya tercipta sebuah sinergi. Sinergi tersebut bertujuan supaya terciptalah kualitas kegiatan yang semakin baik, karena menurut teori Arsitektur Biofilia, pada hakekatnya secara psikologis aktivitas manusia dapat semakin berkualitas jika manusia menempatkan dirinya untuk kembali bersinggungan dengan alam.

Walaupun demikian, terdapat beberapa poin parameter kajian Arsitektur Biofilia yang belum diimplementasikan oleh arsitek pada perancangan ruang kerja di hunian yang menjadi obyek pengamatan. Beberapa poin tersebut antara lain, kehadiran elemen air, prospek, serta kajian terkait tempat perlindungan. Poin-poin tersebut yang belum terdapat pada perancangan ruang kerja bukanlah tanpa alasan. Beberapa parameter memang tidak bisa diterapkan secara gamblang pada aspek perencanaan pengembangan sebuah hunian, khususnya rumah tumbuh. Contohnya seperti poin Prospek dan Tempat Perlindungan, dimana poin ini akan lebih tepat jika diimplementasikan pada proses perencanaan awal sebuah bangunan, bukan pada proses pengembangan.

Kesimpulan akhir dapat dinyatakan bahwa konsep Arsitektur Biofilia telah menjadi rujukan pada proses pengembangan sebuah rumah yang bertumbuh yang menjadi obyek pengamatan. Walaupun belum semua aspek parameter menjadi rujukan dalam penerapan konsep Arsitektur Biofilia, namun pengguna sudah dapat merasakan kualitas dan pengalaman dalam beraktivitas work from home. Hal ini dikarenakan adanya usaha dalam perancangan untuk melibatkan kehadiran elemen alam.

\section{Saran}

Sebagai saran bagi pembaca, dalam menerapkan konsep Arsitektur Biofilia hendaknya dapat mempelajari secara detail poin-poin yang menjadi tolok ukur implementasi konsep ke dalam desain rancangan. Penerapan seluruh poin dalam tolok ukur Arsitektur Biofilia akan membuat pengguna dalam bangunan mengalami keterlibatan alam dalam aktivitasnya secara komprehensif. 


\section{Daftar Pustaka}

Almusaed, Amjad. 2011. Biophilic and Bioclimatic Architecture. Analytical Therapy for the Next Generation of Passive Sustainable Architecture. Denmark: Springer

Almusaed, Amjad. 2006. Biophilic Architecture: Towards a new potential of healthy architecture, rethinking sustainable construction. Proceeding of the 12th Rinker International Conference. Sarasota FL USA

Browning, William. 2014. 14 Patterns of Biophilic Design. USA: Terapi

Kuncoro, Hadi (2020) Pola Konsumsi Masyarakat Selama WFH dalam www.bisnis.com

Laersen, L. (1998) Plants in the workplace: The effects of plant density on productivity, attitudesm and preceptions. Environ Behaviour. 